\title{
"Dynamic capital structure in Indonesian case: do industry-specific variables affect adjustment speeds?"
}

\begin{tabular}{|c|c|}
\hline AUTHORS & $\begin{array}{l}\text { Satriyo Budi Cahyono (D https://orcid.org/0000-0001-8369-384X } \\
\text { Arvinder Singh Chawla (D https://orcid.org/0000-0003-4196-9830 }\end{array}$ \\
\hline ARTICLE INFO & $\begin{array}{l}\text { Satriyo Budi Cahyono and Arvinder Singh Chawla (2019). Dynamic capital } \\
\text { structure in Indonesian case: do industry-specific variables affect adjustment } \\
\text { speeds?. Investment Management and Financial Innovations, 16(2), 218-235. } \\
\text { doi:10.21511/imfi.16(2).2019.19 }\end{array}$ \\
\hline DOI & http://dx.doi.org/10.21511/imfi.16(2).2019.19 \\
\hline RELEASED ON & Wednesday, 12 June 2019 \\
\hline RECEIVED ON & Wednesday, 27 March 2019 \\
\hline ACCEPTED ON & Friday, 31 May 2019 \\
\hline LICENSE & $\begin{array}{l}(c)) E Y \\
\text { This work is licensed under a Creative Commons Attribution } 4.0 \text { International } \\
\text { License }\end{array}$ \\
\hline JOURNAL & "Investment Management and Financial Innovations" \\
\hline ISSN PRINT & $1810-4967$ \\
\hline ISSN ONLINE & $1812-9358$ \\
\hline PUBLISHER & LLC "Consulting Publishing Company "Business Perspectives" \\
\hline FOUNDER & LLC "Consulting Publishing Company "Business Perspectives" \\
\hline
\end{tabular}

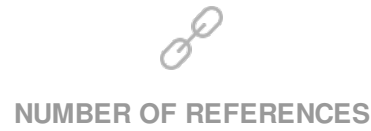

55
NUMBER OF FIGURES

0
NUMBER OF TABLES

7

(C) The author(s) 2022. This publication is an open access article. 


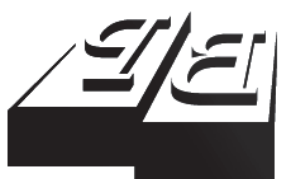

BUSINESS PERSPECTIVES

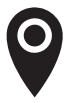

LLC "CPC "Business Perspectives" Hryhorii Skovoroda lane, 10, Sumy, 40022, Ukraine

www.businessperspectives.org

Received on: $27^{\text {th }}$ of March, 2019 Accepted on: $31^{\text {st }}$ of May, 2019

(C) Satriyo Cahyono

Arvinder Chawla, 2019

Satriyo Cahyono, Ph.D. Student, Research Scholar, School of Management Studies, Faculty of Business Study, Punjabi University Patiala, India.

Arvinder Chawla, Ph.D., Professor, School of Management Studies, Faculty of Business Study, Punjabi University Patiala, India.

\section{() (i)}

This is an Open Access article, distributed under the terms of the Creative Commons Attribution 4.0 International license, which permits unrestricted re-use, distribution, and reproduction in any medium, provided the original work is properly cited.

\section{DYNAMIC CAPITAL STRUCTURE IN INDONESIAN CASE: DO INDUSTRY-SPECIFIC VARIABLES AFFECT ADJUSTMENT SPEEDS?}

\begin{abstract}
The authors investigate the firm's capital structure in the dynamic framework and adjustment speeds toward target leverage among Indonesian firms from 2005 to 2016. The sample firms are 407 non-financial listed companies and classified into 8 sectors based on Jakarta Industrial Sector Classification (JASICA).

The explanatory variables consist of firm-level variables viz. size, growth opportunity, profitability, asset structure, liquidity, and firm risk; as well as industry-specific variables viz. industry concentration, munificence, and dynamism. By using dynamic adjustment model, it was found Indonesian firms have target leverages, and they tend to adjust toward their desired debt ratio. Based on country-level analysis, adjustment speeds toward target leverage are from around $30.20 \%$ to $36.97 \%$ per year. Meanwhile, on sector-level analysis, paces of adjustment indicate variety of adjustment speeds across sectors ranged from $26.00 \%$ to $48.32 \%$ per year.
\end{abstract}

The authors also demonstrate that industry-specific variables have substantial influences on adjustment speeds toward target leverage. Industry concentration and industry munificence positively affect adjustment speeds, whereas however industry dynamism fails to show significant effect.

\section{Keywords}

dynamic capital structure, adjustment speed, industryspecific variables, across sectors, Indonesia

\section{JEL Classification}

E22

\section{INTRODUCTION}

During some previous decades, firm's financial structure has become a key concern in modern corporate finance literature. Whether a proper financing decision influences the value of a firm has become a debatable subject in theoretical, as well as in empirical research (Hatfield, Cheng, \& Davidson, 1994). Not long after declared irrelevant financial structure hypothesis (Modigliani \& Miller, 1958), the prominent capital structure theories emerged to explain firm financing behavior. Furthermore, the various studies also try to describe in the context of taxes, agency cost, financing hierarchy, and market timing hypothesis to find out the mechanism of firm's debt-equity structure. According to Kundakchyan and Zulfakarova (2014), the optimal financial structure of a company could be attained by weighting average cost of capital; in other words, an optimal mix consists of debt and equity financing which minimize firm's return on capital and eventually maximize the value of a firm. However, Fama and French (2002) noted that all these theories have limitations in explaining the firm capital structure.

Industries might respond in different ways as changes happened in their environment, and these reactions could influence association 
between leverage and determinants. Mackay and Phillips (2005) highlighted the substance of industry factors affecting firm's financial structure at intra-industry level, which implies that a firm's financing decision relies on its position within a concerning sector. Their argument is in parallel with Ozkan (2001) who proposed that firms within an industry might encounter similar conditions like tax status, risk behavior, and leverage ratios. Ovtchinnikov (2010) argued that firms within a particular industry are sensitive to shocks in external environment, such as deregulation. Consequently, firm's financing decisions are affected by fluctuations in their environment as sector- or industry-specific factors. Due to industry-related adjustment costs, firm's optimal leverage could be different among sectors, although it is possibly similar within intra-sector level. However, these empirical studies mostly focused on the importance of industry factor in capital structure determination across developed markets. In the context of emerging markets, the study of capital structure which investigates industry-specific variable still gets little attention from research scholars.

According to Eldomiaty (2007), the deficiency of capital structure literature within the emerging markets is primarily attributable to some reasons, viz. (1) emerging capital markets are incomplete and less efficient compared to developed market, which makes firms encounter difficulties in deciding types of their financing, (2) the informational asymmetry within emerging markets is relatively higher than developed market, which leads to difficulties for firms in raising capital or reaching optimal capital structure, (3) emerging market has different institutional setting from those in developed market. Therefore, comprehensive and extensive study should be conducted to overcome the problems commonly faced in emerging markets, including Indonesia.

As an emerging market, the Indonesian economy has become an economic powerhouse, which undergone exceptional developments in the past few years (EUIBN, 2017). It is predicted that Indonesia would become the 10th largest economy in the world due to recent economic performance that established it as the second fastest growing G20th economy in 2013, after China, with a strong and stable average growth of $6 \%$ over the last decade (EUIBN, 2017). The large domestic market, sizeable and young workforce, abundant natural resources, and sound macroeconomic fundamentals provide good opportunities, which attract more investors, both debt and equity investors, to the Indonesian market.

Back to history, when the Asian financial crisis in 1997-1998 happened, the Indonesian market was severely plunged into a deep recession. At that time, the economic and political situation became worse, for example, the local currency was highly depreciated, interest rate jumped highly, access to credits became more difficult, and also the share prices have dropped and became illiquid (Tambunan, 2010). In this severe condition, it is difficult for firms to survive and seek a source of funds, both debt and equity financing. As the Indonesian government could not overcome this crisis, it needed financial assistance from the International Monetary Fund (IMF). Initially, the reform packages offered by the IMF were unsuccessful, many banks suffered from liquidity problem and negative spread, which forced them to shut down their operation. As economic condition became worse, this financial crisis turned into a political and social crisis, which compelled the fall of new order regime and breakdown of the patronage system. After Mr. Soeharto's replacement, the IMF approach was rather loose than before, and new reform packages showed better progress marked with starting private capital inflows to the Indonesian market. These reformation processes in Indonesia provide better access to the financial market, which influences firm managers in making decisions regarding their financing choices (Ameer, 2010).

Different from the 1997-1998 Asian Crisis, the 2008-2009 Global Crisis was deemed by analysts as the most serious financial crisis after 1930s Great Depression (Tambunan, 2010). Surprisingly, developing countries in Asia and the Pacific region, including Indonesia, had better performance than countries from other regions during this crisis. Since export was an important source of income, Indonesia considered the 2008-2009 financial crisis as a global market crisis, which most influenced the export-oriented firms (Tambunan, 2010). As the firm's profitability decreased and became volatile, their financing 
policies were surely affected by this global market decline. These two big financial crises and financial reformations furnish an interesting platform to further study regarding the applicability of capital structure theory within an emerging market.

Considering the scarcity of literature in emerging market, the essence of financial reformations, and two big financial crises, which influence Indonesian firm financing decision, this study is motivated to investigate whether capital structure theories are able to explain the firm's financing behaviors in the Indonesian market, in which economically and intuitionally they are very different from those in developed markets.

In the context of Indonesian studies, this research contributes to the capital structure literature in the dynamic framework by using relatively new data (2005-2016) compared to previous studies, e.g. Haron (2016) used data for 2000-2011, Hardiyanto, Achsani, Sembel, and Maulana (2014a) used data for 20052011 and Ameer (2010) used data for 1991-2004. Furthermore, this research also provides empirical evidence of dynamic capital structure, both in country-level and sector-level study, within an emerging market scope. Past researches focused on country-level studies, e.g. Haron (2016), Reinhard and Li (2010), or within a particular sector, e.g. Maruli Tua Sitorus, Priyarsono, Manurung, and Maulana (2014), Nugroho, Siregar, Manurung, and Nuryartono (2015), Saadah and Prijadi (2012). Nevertheless, their researches have not investigated dynamic capital structure across sectors in Indonesia. Some scholars also highlight the importance of sector in dynamic capital structure study, e.g. Hardiyanto et al. (2014a), however, their study merely captured the indirect effect of industry factor as dummy variables. Hence, we analyze the dynamic capital structure and adjustment speed across sectors by putting attention on an emerging market perspective.

By using the dynamic model of capital structure, we found that Indonesian firms tend to rebalance from current leverage, which substantiates the dynamic trade-off theory. The adjustment speed toward target leverage is from around $30.20 \%$ to $36.97 \%$ per year, which is close to the previous study, e.g. Flannery and Rangan (2006), Reinhard and Li (2010). At sector-level analysis, adjustment speeds indicate heterogeneity across sectors, which sustains past studies, e.g. Banerjee, Heshmati, and Wihlborg (2000), Elsas and Florysiak (2011), Getzmann, Lang, and Spremann (2014). The adjustment speeds across sectors ranged from $26.00 \%$ to $48.32 \%$ per year due to sector-related adjustment costs (Elsas \& Florysiak, 2011). We also found that industry-specific variables influence adjustment speeds toward desired leverage. Industry concentration and industry munificence significantly and positively affect adjustment speeds, whereas industry dynamism does not show significant impact adjustment speeds, though it indicates a negative sign.

The organization of the paper is as follows: the paper starts with the introduction section; section 1 provides the literature review to develop the hypotheses of this study, Section 2 elaborates methodology of this paper, describes data and sample, variables of studies, and empirical model of research, Section 3 discusses results and findings of study, and last section provides main conclusions.

\section{REVIEW OF LITERATURE}

According to dynamic capital structure literature, e.g. Chakraborty (2010), Flannery and Rangan (2006), Guney, Li, and Fairchild (2011), firms tend to rebalance their debt ratio to achieve optimal leverage. The dynamic model of capital structure proposes that firms might deviate systematically from their desired leverage due to existence of recapitalization costs (Fischer, Heinkel, \& Zechner,
1989). Furthermore, deviation between observed debt ratio and optimal leverage might vary among firms due to variety in corporate recapitalization costs. Firms are willing to restructure their capital at any point, but transaction costs burden them in rebalancing process.

In existence of transaction costs, firms could not adjust their leverage regularly. Leary and Roberts (2005) documented that firms tend to rebalance 
their leverage generally once a year. Firm's digression could get away from optimal leverage, as adjustment costs are substantial and exceed benefits (Myers, 1984). The adjustment speeds diverge across firms and periods as a result of different recapitalization costs (Hovakimian, Opler, \& Titman, 2001). The slow adjustment speeds happen when rebalancing costs are higher. Conversely, lower rebalancing costs drive quicker adjustment speeds toward desired leverage. As a result, there is trade-off choice between recapitalization costs and being off-target costs. It could happen if change of actual leverage is equivalent with change of target leverage; thus, nothing happens with leverage adjustment and firms set current leverage same with past leverage.

Industries might respond in different ways as the changes happen in their environment, and these reactions could influence the association between firm-level determinants and debt ratio. Furthermore, Ovtchinnikov (2010) argued that the firms within particular industries are very sensitive to the shocks in the external environment, such as deregulation. Consequently, the firm's financing decision is highly affected by the fluctuations in their operating environment as the sector-or industry-specific factors. Due to the presence of industry-related costs of adjustment, the firm's desired debt ratio could be different among sectors, although it is possible being similar within the intra-sector level.

A study by Banerjee et al. (2000) investigated dynamic capital structure in US and UK firms by dividing firms into 9 industries according to 1-digit SIC. In their dynamic model, the industry dummy variables were included to control for any industry-specific effects, which might not be captured by the firm-specific variables. They found that optimal debt ratio and adjustment speeds vary across industries in both countries. And adjustment speeds of industries in the US are mostly quicker than those of industries in the UK, except for industry SIC-7.

Another study by Elsas and Florysiak (2011) documented diversity in adjustment speeds across industries in the US. Substantiating Almazan and Molina (2005), Mackay and Phillips (2005) argue that the firm's industry affiliation might influence capital structure at the industry level, Elsas and Florysiak (2011) revealed that leverage adjustment toward target debt ratio could be similar within industries and heterogeneous across industries due to industry-related rebalancing costs. They found that the adjustment speed indicates some heterogeneity across industries. The average speed across industries is around $25.8 \%$ per year, and the highest speed is about $40 \%$ per year. These scholars argued that the reason for heterogeneity of adjustment speeds across sectors is attributable to the heterogeneous transaction costs of individual industry. Some industries in the US, such as textile, show larger deviations from average adjustment speeds, mainly due to increased transaction costs, which lead to slower adjustment speeds. Meanwhile, other industry, such as metal refinement, indicated faster adjustment speed due to a large amount of capital need and frequent transactions in the capital market.

A recent study by Getzmann et al. (2014) compared 8 industries form 11 Asian stock exchanges. They found that adjustment speeds show diversity across industries, and the firms tend to rebalance to their optimal capital structure with adjustment paces around $24-45 \%$ per year. Furthermore, the firm's capital structure decisions are highly affected by industry fixed effects. Nevertheless, their study examined adjustment speeds across sectors by polling industry data of Asian countries, rather than investigated across sectors from country to country.

In the Indonesian research area, several empirical studies highlighted that industry or sector play an important role in capital structure determination. For example, Hardiyanto, Achsani, Sembel, and Maulana (2014b), Santi (2003) captured industry factor by including it as dummy variables in their models and found the significant role of industry dummy as capital structure determinant. Also, Haron (2018) documented that industry-specific variables, namely industry concentration, industry munificence, and industry dynamism, influence significantly on capital structure among Indonesian firms. However, these researches investigate different capital structure across sectors in the static capital structure framework.

The Indonesian studies of dynamic capital structure context has been conducted by many re- 
searchers and found that adjustment speed toward target leverage was relatively quick, for example Hardiyanto et al. (2014a) - 43.79\% per year, Haron (2016) - 62.74\% per year, Ameer (2010) - 61.92\%$58.08 \%$ per year, and Reinhard and Li (2010) $36 \%-46 \%$ per year. However, these studies have not investigated the dynamics of capital structure, which diverges across industries in Indonesia. Therefore, this study fills the gap of literature in the dynamic version of capital structure, which emphasizes the industry role and focuses on an emerging market.

Based on literature elaborated before, the study hypotheses are summarized as follows:

H1: $\quad$ Target debt ratios across sectors exist, and Indonesian firms follow dynamic capital structure theory.

H2: Adjustment speeds toward target debt-ratios vary across sectors.

H3: Industry-specific variables significantly impact on adjustment speeds toward target leverage.

\section{METHODOLOGY}

\subsection{Data and samples}

The data sources are primarily taken from Thomson Reuters Eikon from 2005 until 2016. The sample firms are all non-financial companies listed in Indonesian Stock Exchange (IDX) and classified into 8 sectors according to Jakarta Industrial Sector Classification (JASICA). The final sample consists of 407 firms with total observation as 3,154 firmyears. To remove fluctuation effect of local currency (IDR), we used USD as monetary units. We also winsorized firm-level explanatory variable at $1 \%$ on both distribution tails to avoid outlier effects.

\subsection{Variables}

\subsubsection{Independent variable (BDR)}

The definitions of leverage have been broadly utilized in some literature; however, those definitions are indecisive and depend on analysis aims (Rajan
\& Zingales, 1995). Previous studies provide pros and cons using book leverage, as well as market leverage. Some scholars, e.g. Rajan and Zingales (1995), Welch (2004), prefer to utilize book leverage, while others, e.g. Mitton (2008), Titman and Wessels (1988), favor using market leverage. A study conducted by Flannery and Rangan (2006) acquired equivalent outcomes when using both market and book debt ratio, whereas Fama and French (2002) found strikingly discrepancy results between both leverage measurements. According to Thies and Klock (1992), in dynamic framework analysis, book value gives a superior expression of firm's target book ratio compared to market value, which is dependent on some factors beyond management's control. Therefore, this study uses book leverage (BDR) as the dependent variable, which is calculated by total debt over total assets.

\subsubsection{Explanatory variables}

Since a firm's optimum debt ratio is unobservable, the proxy selection is essential due to the outcomes being highly relied on measurements utilized in empirical tests. Based on previous researches, some proxies generally used are industry-median debt ratio, mean debt ratio, moving average ratio, and fitted value from regression (Buvanendra, Sridharan, \& Thiyagarajan, 2017). Following Flannery and Rangan (2006), Hovakimian et al. (2001), Ozkan (2001), optimal debt ratio is derived by fitted value from a linear regression of debt ratio on a set of determinants.

\section{Size (SIZE)}

As firm size increases, probability of default becomes lower, and borrowing capacity also increases. The large firms are usually less informationally asymmetrical, so they have better access to financial market at lower costs (Antoniou, Guney, \& Paudyal, 2008; Flannery \& Rangan, 2006; Ozkan, 2001). Firm size is measured by natural logarithm of sales.

\section{Growth opportunity (GROW)}

The firms tend to make equity issuance as their share price is relatively higher than book value or earnings (Ozkan, 2001); thus, growth opportunities should be negatively affected by leverage. 
Growth opportunity is calculated by firm market value over total assets.

\section{Profitability (PROF)}

Profitable firms favor utilizing accumulated earning in financing their investments (Antoniou et al., 2008). On the other hand, as profitability is high, creditors are willing to provide more loan due to increasing payment ability (Ozkan, 2001). Profitability is measured by net operating income over total assets.

\section{Tangibility (TANG)}

The firms with higher tangible assets encourage to borrow more due to collateral availability and lower costs of debt (Chakraborty, 2010; Lemmon et al., 2008; Sbeiti, 2010). Tangibility is calculated by property and plant assets over total assets.

\section{Liquidity (LIQU)}

Liquidity positively influences leverage, because firms have greater short-term debt coverage when it is due (Ozkan, 2001). On the another hand, it indicates a negative relationship as highly liquid firms utilize these assets to fulfill their financing needs (Guney et al., 2011; Sbeiti, 2010). Liquidity is calculated by current assets divided by current liability.

\section{Business risk (RISK)}

Based on the trade-off theory and pecking order hypothesis, firms tend to diminish leverage consumption when their earnings become more uncertain (Antoniou et al., 2008). Firm risk is measured by standard deviation of EBIT to total assets.

\section{Industry concentration (HHIC)}

The firms operating within high industry concentration tend to generate high profits due to less competition degree among firms within an industry (Kayo \& Kimura, 2011). Industry concentration is measured by summing squares of each firm's market share in a particular industry.

\section{Industry munificence (MUNI)}

Firms operating within higher industry munificence tend to have higher profitability due to abundance of resources within a particular industry (Kayo \& Kimura, 2011). Industry munificence is measured by making time regression against sales of a particular industry during past five years, then calculating the ratio of slope coefficient of regression over mean value of sales.

\section{Industry dynamism (DYNA)}

Firms operating within higher industry dynamism are exposed to greater risk level, mainly due to rapid environmental changes, which lead to business uncertainty. Thus, higher industry concentration drives firms to reduce their leverage dependency (Kayo \& Kimura, 2011). Industry dynamism is measured by the standard error of slope coefficient from the munificence regression over the mean value of sales.

\subsection{Empirical models}

\subsubsection{Dynamic framework of capital structure}

As suggested by Flannery and Rangan (2006), optimal leverage is a function of several predictors as follows:

$$
D R_{i t+1}^{*}=\beta_{n} x_{n, i t}+\gamma_{n} z_{n, j t}+\varepsilon_{i t+1}
$$

where $D R_{i t+1}^{*}$ is targeted debt ratio of firm $i$ in period $t+1, x_{n, i t}$ is the vector of firm-specific variables of firm $i$ in period $t, z_{n, j t}$ is the vector of industry-specific variables of industry $j$ in period $t, \beta_{n}$ is unknown parameters of firm-specific variables and $\gamma_{n}$ is unknown parameters of industry-specific variables, $\varepsilon_{i t+1}$ is error term to be assumed zero mean and constant variant.

The partial adjustment model illustrates that firms rebalance their observed debt ratio with adjustment coefficient $\lambda$ to pursue their optimal debt ratio level as follows:

$$
D R_{i t+1}-D R_{i t}=\lambda\left(D R_{i t+1}^{*}-D R_{i t}\right)+\varepsilon_{i t+1} .
$$

Equation (2) can be expressed as follows:

$$
D R_{i t+1}=(1-\lambda) D R_{i t}+\lambda D R_{i t+1}^{*}+\varepsilon_{i t+1}
$$

where $D R_{i t+1}$ is observed debt ratio of firm $i$ in period $t+1, D R_{i t+1}^{*}$ is desired target debt ratio of 
the firm, $D R_{i t}$ is observed lag debt ratio of firm $i$ in period $t, D R_{i t+1}^{*}-D R_{i t}$ is the change of target debt ratio, while only a portion of $\lambda$ of the change of observed debt ratio achieved, which is equal to $D R_{i t+1}-D R_{i t}$. The coefficient $\lambda$ represents convergence rate or adjustment speed toward the target debt ratio, $\varepsilon_{i t+1}$ is an error term that should not be correlated with right side of regression, $\lambda$ is adjustment speed, which represents deviating away from target leverage.

Some studies such as Flannery and Rangan (2006), Ozkan (2001) integrated equation (1) into equation (3) to attain dynamic model of partial capital structure adjustment as follows:

$$
\begin{aligned}
& D R_{i t+1}=(1-\lambda) D R_{i t}+\lambda \beta_{n} x_{n, i t}+ \\
& +\lambda \gamma_{n} z_{n, j t}+\lambda \varepsilon_{i t+1} .
\end{aligned}
$$

The coefficient of lag debt ratio $1-\lambda$ in equation (4) will produce a single number of regression parameter, hence it can be named as the integrated dynamic model with common coefficient. To know regression coefficients of lag debt ratio for each observed period, this equation will include a different coefficient for each period unit as follows:

$$
\begin{aligned}
& D R_{i t+1}=(1-\lambda)_{t} D R_{i t}+\lambda \beta_{n} x_{n, i t}+ \\
& +\lambda \gamma_{n} z_{n, j t}+\lambda \varepsilon_{i t+1} .
\end{aligned}
$$

The coefficient of lag debt ratio $1-\lambda$ in equation (5) will generate different regression parameter for each period of observations, hence, it can be named as the integrated dynamic model with period-specific coefficient.

Based on these equations, $\lambda=0$ means that firms do not make leverage adjustment, thus, they arrange their current leverage same as their past debt ratio, $\lambda=1$ implies that firms completely adjust for deviation from their desired debt ratio quickly with zero rebalancing costs, $\lambda<1$ indicates that firms partially adjust into undesired leverage ratio due to adjustment costs, and $\lambda>1$ means that firms make excessive adjustment than necessary and eventually are unable to achieve the optimum level. Generally, value of convergence rate or $\lambda$ ranges from 0 to 1 due to adjustment process. The half-life of leverage is defined as time needed by firms to rebalance to their optimal debt ratio after a one unit shock, i.e. $\ln (0.5) / \ln (1-\lambda)$.

\subsubsection{Impact of industry-specific variables on the speed of adjustment}

In this subsection, this study analyzes impact of industry-specific variables viz. industry concentration, munificence, and dynamism on adjustment speed toward target leverage. Firstly, we measure adjustment speed for each sector using integrated dynamic model with period-specific coefficients as follows:

$$
D R_{i t+1}=(1-\lambda)_{t} D R_{i t}+\lambda \beta_{n} x_{n, i t}+\lambda \varepsilon_{i t+1} .
$$

where $D R_{i t+1}$ is observed debt ratio of firm $i$ in period $t+1, D R_{i t}$ is lag debt ratio of firm $i$ in period $t,(1-\lambda)_{t}$ is lag debt ratio period-specific coefficients, $\lambda$ is adjustment speed, $x_{n, i t}$ is vector of firm-specific variables of firm $i$ in period $t, \beta$ is unknown parameters of firm-specific variables, $\varepsilon_{i t+1}$ is is error term.

Secondly, we estimate equation (6) for each sector and produce a different coefficient of lag debt ratio $1-\lambda$ for each observed periods. Next, pooled adjustment speeds $\lambda_{j t}$ are derived from adjustment speed of each sector $j$ during observed period $t$. Finally, we regress pooled adjustment speed on industry-specific variables as follows:

$$
\lambda_{j t}=\delta_{n} z_{n, j t}+\varepsilon_{j t},
$$

where $\lambda_{j t}$ is adjustment speed of sector $j$ in period $t, z_{n, j t}$ is vector of industry-specific variables viz, industry concentration, munificence, and dynamism, $\varepsilon_{j t}$ is error term, and $\delta_{n}$ is unknown parameters of industry-specific variables.

\section{RESULTS AND DISCUSSIONS}

\subsection{Summary statistics}

Table 1 exhibits that sample firms and observation numbers vary across sectors from 2005 to 2016. Trade and Service sector has largest sample and observation numbers, whereas Agricultural sector has the smallest ones. The 
importance of debt financing is noticeable across Infrastructure sector and Miscellaneous Industry firms. Meanwhile, Property sector and Consumer Goods Industry firms utilize less debt financing. These data highlights that leverage utilization is divergent across sectors among Indonesian firms.

\subsection{Explanatory variable analysis}

Table 2 shows that the highest correlation coefficients amongst independent variables are between size and profitability $(r=0.390, \rho=0.01)$, as well as between growth opportunity and profitability $(r=0.318, \rho=0.01)$. This indicates that the higher profitability of a firm makes it grow more rapidly, and eventually its size becomes larger. Also, the Variance Inflation Factor (VIF) is measured to ensure no multicollinearity issue.

Table 1. Descriptive statistics
Since all correlation coefficients and VIF are low (i.e., $r<0.95$ and VIF $<10$ ), multicollinearity problem between explanatory variables is not a concern (Gujarati, Porter, \& Gunasekar, 2012). The Pearson correlation and VIF are also calculated for each sector (not reported), and the results indicate no multicollinearity problems.

\subsection{Full sample analysis (country-level)}

The country-level analysis as in Table 3 and Table 4 indicate the substance of lag debt ratio $D R_{i t}$ on the observed debt ratio $D R_{i t+1}$ being apparent across all dynamic regression methods. This finding supports the presence of optimal financial structure among Indonesian firms and sustains dynamic trade-off theory. It provides an empirical evidence, which confirms the previous Indonesian research-

\begin{tabular}{|c|c|c|c|c|c|c|c|c|c|c|}
\hline & & \multicolumn{8}{|c|}{ SECTORS } & \multirow{2}{*}{$\begin{array}{c}\text { FULL } \\
\text { SAMPLE }\end{array}$} \\
\hline & & 1_AGRI & 2_MINI & 3_BASI & 4_MISC & 5_CONS & 6_PROP & 7_INFR & 8_TRAD & \\
\hline \multicolumn{2}{|c|}{ No. of firms } & 21 & 42 & 59 & 36 & 35 & 52 & 50 & 112 & 407 \\
\hline \multicolumn{2}{|c|}{ No. of obs. } & 153 & 315 & 480 & 324 & 307 & 425 & 335 & 815 & 3154 \\
\hline \multicolumn{11}{|c|}{ Dependent variables } \\
\hline \multirow{2}{*}{ BDR } & Mean & 0.276 & 0.246 & 0.290 & 0.391 & 0.177 & 0.169 & 0.473 & 0.221 & 0.268 \\
\hline & S.D. & 0.198 & 0.217 & 0.229 & 0.457 & 0.192 & 0.135 & 0.435 & 0.206 & 0.267 \\
\hline \multicolumn{11}{|c|}{ Explanatory variables - firm-specific } \\
\hline \multirow{2}{*}{ SIZE } & Mean & 18.585 & 18.524 & 18.647 & 18.896 & 18.972 & 17.830 & 18.350 & 18.016 & 18.376 \\
\hline & S.D. & 1.946 & 2.383 & 1.622 & 1.387 & 1.740 & 1.687 & 2.063 & 2.138 & 1.940 \\
\hline \multirow{2}{*}{ GROW } & Mean & 2.459 & 1.583 & 1.057 & 0.905 & 2.387 & 1.019 & 1.496 & 1.451 & 1.409 \\
\hline & S.D. & 4.366 & 1.599 & 0.842 & 0.628 & 3.012 & 0.718 & 1.145 & 1.612 & 1.539 \\
\hline \multirow{2}{*}{ PROF } & Mean & 0.085 & 0.072 & 0.067 & 0.053 & 0.147 & 0.062 & 0.044 & 0.056 & 0.070 \\
\hline & S.D. & 0.110 & 0.146 & 0.090 & 0.079 & 0.171 & 0.054 & 0.138 & 0.121 & 0.113 \\
\hline \multirow{2}{*}{ TANG } & Mean & 0.679 & 0.642 & 0.808 & 0.814 & 0.540 & 0.260 & 1.001 & 0.529 & 0.622 \\
\hline & S.D. & 0.273 & 0.387 & 0.383 & 0.508 & 0.234 & 0.241 & 1.026 & 0.400 & 0.435 \\
\hline \multirow{2}{*}{ LIQU } & Mean & 4.151 & 3.652 & 2.211 & 1.524 & 2.837 & 2.589 & 1.603 & 2.853 & 2.464 \\
\hline & S.D. & 10.513 & 9.359 & 2.145 & 0.903 & 2.052 & 3.275 & 2.366 & 6.165 & 3.799 \\
\hline \multirow{2}{*}{ RISK } & Mean & 0.003 & 0.005 & 0.002 & 0.001 & 0.004 & 0.001 & 0.018 & 0.004 & 0.003 \\
\hline & S.D. & 0.011 & 0.011 & 0.003 & 0.002 & 0.018 & 0.002 & 0.119 & 0.021 & 0.011 \\
\hline \multicolumn{11}{|c|}{ Explanatory variables - industry-specific } \\
\hline \multirow{2}{*}{$\mathrm{HHIC}$} & Mean & 0.167 & 0.090 & 0.060 & 0.381 & 0.145 & 0.061 & 0.187 & 0.045 & 0.119 \\
\hline & S.D. & 0.012 & 0.015 & 0.004 & 0.042 & 0.018 & 0.011 & 0.055 & 0.006 & 0.103 \\
\hline \multirow{2}{*}{ MUNI } & Mean & 0.132 & 0.124 & 0.120 & 0.112 & 0.104 & 0.183 & 0.119 & 0.161 & 0.138 \\
\hline & S.D. & 0.125 & 0.178 & 0.073 & 0.073 & 0.051 & 0.079 & 0.076 & 0.088 & 0.099 \\
\hline \multirow{2}{*}{ DYNA } & Mean & 0.050 & 0.033 & 0.026 & 0.025 & 0.022 & 0.022 & 0.014 & 0.025 & 0.025 \\
\hline & S.D. & 0.016 & 0.016 & 0.008 & 0.011 & 0.007 & 0.005 & 0.007 & 0.011 & 0.013 \\
\hline
\end{tabular}

Note: This table shows descriptive statistics based on the full sample, as well as across sectors dataset. The sample divided firms are sectors, according to JASICA (Jakarta Industrial Classification) as follows: AGRI = Agriculture; MINI = Mining; BASI = Basic Industry and Chemical; MISC = Miscellaneous Industry; CONS = Consumers Good Industry; PROP = Property, Real estate, and Building Construction; INFR = Infrastructure, Utility and Transportation; TRAD = Trade, Service and Investment. The Banking and Financial sector firms are excluded from this study. The independent variables consist of firm-specific variables (i.e., SIZE = firm size, GROW = growth opportunity, PROF = profitability, TANG = tangibility, LIQU = liquidity, RISK = business risk) and industry-specific variables (i.e., HHIC = industry concentration, MUNI = industry munificence, and DYNA = industry dynamism). 
Table 2. Correlation matrix and VIF

\begin{tabular}{|c|c|c|c|c|c|c|c|c|c|}
\hline \multicolumn{10}{|c|}{ Correlation matrix } \\
\hline & SIZE & GROW & PROF & TANG & LIQU & RISK & HHIC & MUNI & DYNA \\
\hline SIZE & 1 & - & - & - & - & - & - & - & - \\
\hline GROW & 0.016 & 1 & - & - & - & - & - & - & - \\
\hline PROF & $0.390^{* * *}$ & $0.318^{* * *}$ & 1 & - & - & - & - & - & - \\
\hline TANG & -0.002 & 0.009 & $-0.163^{* * *}$ & 1 & - & - & - & - & - \\
\hline LIQU & $-0.254^{* * *}$ & $0.054^{* * *}$ & -0.007 & $-0.193^{* * *}$ & 1 & - & - & - & - \\
\hline RISK & $-0.120^{* * *}$ & $0.172^{* * *}$ & $-0.128^{* * *}$ & $0.100^{* * *}$ & 0.002 & 1 & - & - & - \\
\hline $\mathrm{HHIC}$ & $0.095^{* * *}$ & $-0.033^{*}$ & -0.014 & $0.230^{* * *}$ & $-0.075^{* * *}$ & -0.015 & 1 & - & - \\
\hline MUNI & $-0.192^{* * *}$ & $-0.057^{* * *}$ & 0.016 & $-0.082^{* * *}$ & $0.061^{* * *}$ & $0.041^{* *}$ & $-0.080^{* * *}$ & 1 & - \\
\hline DYNA & 0.023 & $0.035^{* *}$ & 0.025 & -0.007 & $0.060^{* * *}$ & 0.001 & 0.007 & $0.086^{* * *}$ & 1 \\
\hline \multicolumn{10}{|c|}{ Variance Inflation Factor } \\
\hline & SIZE & GROW & PROF & TANG & LIQU & RISK & $\mathrm{HHIC}$ & MUNI & DYNA \\
\hline VIF & 1.370 & 1.210 & 1.430 & 1.140 & 1.130 & 1.080 & 1.070 & 1.080 & 1.020 \\
\hline 1/VIF & 0.731 & 0.828 & 0.697 & 0.876 & 0.888 & 0.923 & 0.934 & 0.928 & 0.985 \\
\hline
\end{tabular}

Note: This table shows that there is no collinearity between independent variables. The independent variables consist of firmspecific variables (i.e., SIZE = firm size, GROW = growth opportunity, PROF = profitability, TANG = tangibility, LIQU = liquidity, RISK = business risk) and industry-specific variables (i.e., HHIC = industry concentration, MUNI = industry munificence, and DYNA $=$ industry dynamism). $P$-values are $* * *$ significant at $1 \%$ level, $* *$ significant at $5 \%$ level, $*$ significant at $10 \%$ level.

es such as Hardiyanto et al. (2014a), Saadah and Prijadi (2012), Wakhidi and Sukarno (2014).

Table 3 exhibits the regression results of the dynamic model using firm-specific variables. The coefficients of the lag dependent variable based on OLS and fixed-effect methods are 0.871 and 0.616 , respectively, which are close to the outcome of a study by Flannery and Rangan (2006) as much as 0.860 and 0.620 , respectively. As proposed by Hsiao (2003), OLS estimator tends to upward biased due to ignorance of fixed effects existence, whereas fixed-effect estimator tends to downward biased. The adjustment speeds based on these methods are $12.88 \%$ and $38.38 \%$ per year, respectively. In other words, leverage half-life times taken by firms to adjust back to their debt ratio are around 5.03 years based on OLS and 1.43 years based on fixed effect estimator. Hence, discrepancy of outcomes between both OLS and fixed effect model is so wide.

Meanwhile, the results of estimation by using twostep GMM-DIF and 2SLS with period-specific coefficient produce nearly close outcomes as 0.698 and 0.630 (on average), respectively. These numbers are consistent with Bond (2002), Flannery and Rangan (2006), where the true coefficient value of the lag dependent variable should lie between OLS and fixed effect. The adjustment speeds based on GMM and 2SLS with period-specific coefficients are $30.20 \%$ and $36.97 \%$ per year, respectively. In other words, leverage half-life times are around 1.93 years using GMM and 1.50 years using 2SLS with period-specific coefficients.

Table 4 exhibits regression results of the dynamic model, which includes industry-specific variables besides firm-specific covariates. Based on all methods of estimator, the coefficient of dependent variable decreases slightly after including industry-specific variables. The coefficient values based on OLS and fixed effect method become 0.868 and 0.612 , respectively. The adjustment speeds based both methods are now $11.38 \%$ and $38.76 \%$ per year, respectively. In other words, half-life times are 4.9 years based on OLS and 1.41 years based on fixed effect estimator.

On the other hand, regression results based on two-step GMM-DIF and 2SLS with period-specific coefficient are 0.698 and 0.626 (on average), respectively. Again, these outcomes are still consistent with argument of Bond (2002), Flannery and Rangan (2006) that true coefficient value of lag dependent variable should lie between OLS and fixed effect. The adjustment speed based on these methods become to $30.25 \%$ and $37.23 \%$ per year, respectively. In other words, leverage half times are around 1.92 years based on GMM and 1.49 years based on 2SLS with period-specific coefficients. From this point, adjustment speeds increase slightly after including industry-specific variables. 
Table 3. Full sample analysis using firm-specific determinants

\begin{tabular}{|c|c|c|c|c|c|c|c|c|}
\hline \multicolumn{3}{|c|}{ Variable } & \multicolumn{6}{|c|}{ BOOK LEVERAGE } \\
\hline \multirow{2}{*}{ Dependent } & \multicolumn{2}{|c|}{ OLS } & \multicolumn{2}{|c|}{ Fixed effect } & \multicolumn{2}{|c|}{ GMM - xtabond2 } & \multicolumn{2}{|c|}{$\begin{array}{l}\text { 2SLS with period- } \\
\text { specific coefficient }\end{array}$} \\
\hline & \multicolumn{2}{|c|}{ BDR $_{t+1}$} & \multicolumn{2}{|c|}{ BDR $_{t+1}$} & \multicolumn{2}{|c|}{ BDR $_{t+1}$} & \multicolumn{2}{|c|}{ BDR $_{t+1}$} \\
\hline No. of firms/obs. & \multicolumn{2}{|c|}{$407 / 3121$} & \multicolumn{2}{|c|}{$407 / 3121$} & \multicolumn{2}{|c|}{$407 / 3154$} & \multicolumn{2}{|c|}{$407 / 3154$} \\
\hline C & -0.0338 & 0.223 & 0.0977 & 0.202 & -0.0619 & 0.656 & 0.1683 & $0.035^{* *}$ \\
\hline $\mathrm{BDR}_{\mathrm{t}}$ & 0.8712 & $0.000^{* * *}$ & 0.6162 & $0.000^{* * *}$ & 0.6980 & $0.000^{* * *}$ & - & - \\
\hline SIZE & 0.0038 & $0.011^{* *}$ & 0.0002 & $0.966^{* * *}$ & 0.0069 & 0.394 & -0.0039 & 0.367 \\
\hline GROW & 0.0013 & 0.465 & 0.0028 & 0.277 & -0.0069 & 0.328 & 0.0028 & 0.281 \\
\hline PROF & -0.1304 & $0.000^{* * *}$ & -0.1816 & $0.000^{* * *}$ & -0.1789 & $0.097^{*}$ & -0.1721 & $0.000^{* * *}$ \\
\hline TANG & 0.0217 & $0.001^{* * *}$ & 0.0300 & 0.031 & 0.0801 & 0.112 & 0.0295 & $0.032^{* *}$ \\
\hline LIQU & -0.0008 & 0.241 & -0.0003 & 0.740 & -0.0014 & 0.302 & -0.0003 & 0.748 \\
\hline RISK & -0.5945 & $0.011^{* *}$ & -1.1198 & $0.000^{* * *}$ & -1.3220 & $0.003^{* * *}$ & -1.1637 & $0.000^{* * *}$ \\
\hline $\mathrm{BDR}_{20.05}$ & - & - & - & - & - & - & 0.6624 & $0.000^{* * *}$ \\
\hline $\mathrm{BDR}_{2006}$ & - & - & - & - & - & - & 0.5101 & $0.000^{* * *}$ \\
\hline $\mathrm{BDR}_{2007}$ & - & - & - & - & - & - & 0.6526 & $0.000^{* * *}$ \\
\hline $\mathrm{BDR}_{2008}$ & - & - & - & - & - & - & 0.6449 & $0.000^{* * *}$ \\
\hline $\mathrm{BDR}_{20.09}$ & - & - & - & - & - & - & 0.6295 & $0.000^{* * *}$ \\
\hline $\mathrm{BDR}_{2010}$ & - & - & - & - & - & - & 0.4900 & $0.000^{* * *}$ \\
\hline $\mathrm{BDR}_{2011}$ & - & - & - & - & - & - & 0.6329 & $0.000^{* * *}$ \\
\hline $\mathrm{BDR}_{2012}$ & - & - & - & - & - & - & 0.6887 & $0.000^{* * *}$ \\
\hline $\mathrm{BDR}_{20.13}$ & - & - & - & - & - & - & 0.6430 & $0.000^{* * *}$ \\
\hline $\mathrm{BDR}_{2014}$ & - & - & - & - & - & - & 0.7224 & $0.000^{* * *}$ \\
\hline \multirow[t]{7}{*}{$\mathrm{BDR}_{20.15}$} & - & - & - & - & - & - & 0.6573 & $0.000^{* * *}$ \\
\hline & $F$-stat & 1282 & $F$-stat & 25.9 & Wald & 249.5 & $F$-stat & 26.4 \\
\hline & Prob. F & $0.000^{* * *}$ & Prob. $F$ & $0.000^{* * *}$ & Prob. $X^{2}$ & $0.000^{* * *}$ & Prob. $F$ & $0.000^{* * *}$ \\
\hline & $R$-squared & 0.74 & $R$-squared & 0.8 & Hansen & 0.482 & $R$-squared & 0.804 \\
\hline & Adj. $R$-sq. & 0.74 & Adj. $R$-sq. & 0.77 & AR-1 & $0.002^{* * *}$ & Adj. $R$-sq. & 0.773 \\
\hline & DW-stat & 2.115 & DW-stat & 2.111 & AR-2 & 0.399 & DW-stat & 2.079 \\
\hline & & & & & Instrument & 379 & Instrument & 424 \\
\hline Speed of adjust & \multicolumn{2}{|c|}{$12.88 \%$} & \multicolumn{2}{|c|}{$38.38 \%$} & \multicolumn{2}{|c|}{$30.20 \%$} & \multicolumn{2}{|c|}{$36.97 \%$} \\
\hline Half-life & \multicolumn{2}{|c|}{5.03} & \multicolumn{2}{|c|}{1.43} & \multicolumn{2}{|c|}{1.93} & \multicolumn{2}{|c|}{1.50} \\
\hline
\end{tabular}

Note: This model is based on equation (4) and equation (5). The dependent variable is BDR = Book to Debt Ratio, and the independent variables consist of firm-specific variables (i.e., SIZE = firm size, GROW = growth opportunity, PROF = profitability, TANG = tangibility, LIQU = liquidity, RISK = business risk). Model-fit statistics are reported at the bottom of the table, $p$-values are $* * *$ significant at $1 \%$ level, $* *$ significant at $5 \%$ level, $*$ significant at $10 \%$ level

Firm size positively impacts on leverage based on OLS estimator only. Trade-off theory suggests that large firms have better business diversification, more stable cash flow, lower default risks, and fewer costs of financial distress; so they possess higher debt capacities and obtain greater tax shield benefit from debts (Antoniou et al., 2008; Chen \& Strange, 2005; de Haas \& Peeters, 2006; Elsas \& Florysiak, 2008; Sbeiti, 2010). Additionally, agency theory proposes that large firms have lower agency costs of debt and less information asymmetry; so they possess greater accessibility in debt market with lower transaction costs (Antoniou et al., 2008; Rajan \& Zingales, 1995; Sbeiti, 2010; Song, 2005).

Profitability consistently exhibits a negative association with leverage, although GMM estima- tor becomes insignificant after including industry-specific variables in the model. Pecking order hypothesis predicts the profitable firms tend to have greater accumulated earnings, so they prefer to utilize their internal resources and minimize their dependency on debt due to higher premium costs of external financing (Antoniou et al., 2008; de Haas \& Peeters, 2006; Myers \& Majluf, 1984; Sbeiti, 2010).

Asset tangibility consistently indicates a positive influence on leverage, even though GMM estimator fails to show a significant outcome. As predicted by trade-off theory, the firm's tangible assets could be utilized as debt guarantee; therefore it can reduce default risk, and creditors will charge at a lower risk premium (Antoniou et al., 2008; Elsas \& Florysiak, 
Table 4. Full sample analysis using firm-specific and industry-specific determinants

\begin{tabular}{|c|c|c|c|c|c|c|c|c|c|c|c|c|}
\hline \multirow{2}{*}{$\begin{array}{l}\text { Dependent } \\
\text { variable }\end{array}$} & \multicolumn{3}{|c|}{ OLS } & \multicolumn{3}{|c|}{ Fixed effect } & \multicolumn{3}{|c|}{ GMM - xtabond2 } & \multicolumn{3}{|c|}{$\begin{array}{l}\text { 2SLS with period- } \\
\text { specific coefficient }\end{array}$} \\
\hline & \multicolumn{3}{|c|}{ BDR $_{t+1}$} & \multicolumn{3}{|c|}{$\mathrm{BDR}_{\mathrm{t}+1}$} & \multicolumn{3}{|c|}{$\mathrm{BDR}_{\mathrm{t}+1}$} & \multicolumn{3}{|c|}{$\mathrm{BDR}_{\mathrm{t}+1}$} \\
\hline No. of firms/obs. & \multicolumn{3}{|c|}{$407 / 3121$} & \multicolumn{3}{|c|}{$407 / 3121$} & \multicolumn{3}{|c|}{$407 / 3154$} & \multicolumn{3}{|c|}{$407 / 3154$} \\
\hline C & -0.0225 & \multicolumn{2}{|c|}{0.448} & 0.1962 & \multicolumn{2}{|c|}{$0.019^{* * *}$} & -0.0710 & \multicolumn{2}{|c|}{0.635} & 0.2073 & \multicolumn{2}{|c|}{$0.015^{* *}$} \\
\hline $\mathrm{BDR}_{\mathrm{t}}$ & 0.8682 & \multicolumn{2}{|c|}{$0.000^{* * *}$} & 0.6124 & \multicolumn{2}{|c|}{$0.000 * * *$} & 0.6975 & \multicolumn{2}{|c|}{$0.000^{* * *}$} & - & \multicolumn{2}{|l|}{-} \\
\hline SIZE & 0.0034 & \multicolumn{2}{|c|}{$0.027^{* *}$} & -0.0032 & \multicolumn{2}{|c|}{$0.462^{* * *}$} & 0.0069 & \multicolumn{2}{|c|}{0.426} & -0.0048 & \multicolumn{2}{|c|}{0.283} \\
\hline GROW & 0.0014 & \multicolumn{2}{|c|}{0.452} & 0.0026 & 0.31 & & -0.0071 & 0.31 & & 0.0027 & 0.28 & 87 \\
\hline PROF & -0.1300 & 0.000 & & -0.1657 & 0.000 & & -0.1826 & 0.10 & & -0.1705 & 0.000 & 0 \\
\hline TANG & 0.0190 & 0.003 & & 0.0299 & 0.032 & & 0.0793 & 0.14 & & 0.0300 & 0.02 & $29 *$ \\
\hline LIQU & -0.0008 & 0.23 & & -0.0004 & 0.70 & & -0.0015 & 0.29 & & -0.0003 & 0.71 & 13 \\
\hline RISK & -0.5730 & 0.014 & & -1.1141 & 0.00 & & -1.3272 & 0.003 & & -1.1821 & 0.000 & $0 * *$ \\
\hline $\mathrm{HHIC}$ & 0.0468 & 0.06 & & -0.2388 & 0.027 & & 0.0095 & 0.96 & & -0.1983 & 0.06 & $69^{*}$ \\
\hline MUNI & -0.0270 & 0.36 & & -0.0445 & 0.19 & & 0.0194 & 0.81 & & 0.0117 & 0.78 & 85 \\
\hline DYNA & -0.1050 & 0.59 & & -0.0412 & 0.86 & & 0.2356 & 0.65 & & -0.0237 & 0.92 & 27 \\
\hline $\mathrm{BDR}_{20.05 . .}$ & - & - & & - & - & & - & - & & 0.6631 & 0.000 & $0^{* * *}$ \\
\hline $\mathrm{BDR}_{2006}$ & - & - & & - & - & & - & - & & 0.5105 & 0.000 & $0^{* * *}$ \\
\hline $\mathrm{BDR}_{20,07 \ldots}$ & - & - & & - & - & & - & - & & 0.6492 & 0.000 & $0^{* * *}$ \\
\hline $\mathrm{BDR}_{2008}$ & - & - & & - & - & & - & - & & 0.6404 & 0.000 & $0^{* * *}$ \\
\hline $\mathrm{BDR}_{20.99 \ldots}$ & - & - & & - & - & & - & - & & 0.6301 & 0.000 & $0^{* * *}$ \\
\hline $\mathrm{BDR}_{2010}$ & - & - & & - & - & & - & - & & 0.4878 & 0.000 & $\mathrm{O}^{* * *}$ \\
\hline $\mathrm{BDR}_{20.11 \ldots}$ & - & - & & - & - & & - & - & & 0.6295 & 0.00 & $\mathrm{O}^{* * *}$ \\
\hline $\mathrm{BDR}_{2012 \ldots}$ & - & - & & - & - & & - & - & & 0.6838 & 0.000 & $\mathrm{O}^{* * *}$ \\
\hline $\mathrm{BDR}_{20.13 \ldots}$ & - & - & & - & - & & - & - & & 0.6366 & 0.000 & $0 * * *$ \\
\hline $\mathrm{BDR}_{20.14 \ldots}$ & - & - & & - & - & & - & - & & 0.7183 & 0.000 & $0^{* * *}$ \\
\hline $\mathrm{BDR}_{20.15 \ldots}$ & - & - & & - & - & & - & - & & 0.6553 & 0.00 & $0^{* * *}$ \\
\hline & $F$-stat & 898.6 & - & $F$-stat & 25.8 & - & Wald & 255.8 & - & F-stat & 26.2 & - \\
\hline & Prob. $F$ & 0.000 & $* * *$ & Prob. $F$ & 0.000 & $* * *$ & Prob. $x^{2}$ & 0.000 & $* * *$ & Prob. $F$ & 0.000 & $* * *$ \\
\hline & $R$-squared & 0.741 & - & $R$-squared & 0.797 & - & Hansen & 0.470 & - & $R$-squared & 0.804 & - \\
\hline & Adj. $R$-sq. & 0.740 & - & Adj. $R$-sq. & 0.766 & - & $A R-1$ & 0.002 & $* * *$ & Adj. $R$-sq. & 0.773 & - \\
\hline & DW-stat & 2.112 & - & DW-stat & 2.110 & - & $A R-2$ & 0.394 & - & DW-stat & 2.077 & \\
\hline & - & - & - & - & - & - & Instrument & 379 & - & Instrument & 427 & \\
\hline Speed of adjust & $13.18 \%$ & - & - & $38.76 \%$ & - & - & $30.25 \%$ & - & - & $37.23 \%$ & - & - \\
\hline Half-life & 4.90 & - & - & 1.41 & - & - & 1.92 & - & - & 1.49 & - & - \\
\hline
\end{tabular}

Note: This model is based on equation (4) and equation (5). The dependent variable is BDR = Book to Debt Ratio, and the independent variables consist of firm-specific variables (i.e., SIZE = firm size, GROW = growth opportunity, PROF = profitability, TANG = tangibility, LIQU = liquidity, RISK = business risk) and industry-specific variables (i.e. HHIC = industry concentration, MUNI = industry munificence, and DYNA = industry dynamism). Model-fit statistics are reported at the bottom of the table, $p$-values are ${ }^{* * *}$ significant at $1 \%$ level, ${ }^{* *}$ significant at $5 \%$ level, $*$ significant at $10 \%$ level.

2008; Sbeiti, 2010). Additionally, agency theory suggests that asset tangibility has a function as collateral to prevent risk-shifting problems and minimize agency costs between shareholder and bondholder (Frank \& Goyal, 2009; Jensen \& Meckling, 2012; Sbeiti, 2010; Titman \& Wessels, 1988).

Firm risk consistently maintains a negative association with leverage across all methods of estimators. Trade-off theory predicts that the firms with greater earnings volatility are not able to fulfill their obligations, which leads to higher cost of financial distress; thus, they will encounter higher difficulties in accessing debt financing (de Haas \&
Peeters, 2006; DeAngelo \& Masulis, 1980; Frank \& Goyal, 2009).

Industry concentration affects negatively on leverage based on fixed-effect and 2SLS estimators, although OLS produces a different outcome. This result is similar with previous studies such as Kayo and Kimura (2011) in developed and emerging economies and Bilal et al. (2014) in Spain and Malaysia. The firms operating in higher concentrated industry generally produce higher profits. Thus, based on pecking order hypothesis, these firms favor utilizing their profits to finance their investments. 


\subsection{Across sectors analysis (sector-level)}

Several past literatures, e.g. Bilal et al. (2014), Kayo and Kimura (2011) have emphasized that firm-level variables as the most crucial determinants, which affect firm's financing choice. Therefore, in sector-level analysis, the dynamic model as in equation (6) focuses on firm-specific covariates as explanatory variables by using 2SLS with the period-specific coefficient estimator to know adjustment speeds per sector for each period.

Table 5 indicates that lag debt ratio $D R_{i t}$ has a substantial role in determining observed debt ratio $D R_{i t+1}$ across sectors and accordingly confirms dynamic trade-off theory. This result shows that each sector has its optimal financial structure, which is different from other sectors. The different adjustment speeds for each sector are due to sector-related adjustment factors such as deregulation, tax status, risk behavior, and so on (Ovtchinnikov, 2010; Ozkan, 2001).

In general, the fastest adjustment speeds are observable among Trade and Service firms and followed by Consumer Good Industry firms with average speed $48.32 \%$ (half-life of 1.05 years) and $47.67 \%$ (half-life of 1.07 years), respectively. These firms take a shorter time to adjust the current position of debt ratio into desired ratio primarily due to highly profitable firms with a moderate level of risks. Meanwhile, the slowest adjustment speeds occur among Infrastructure firms with average speed of $26.00 \%$ (half-life of 2.3 years). These firms take a longer period to attain their desired book leverage due to their difficulties in borrowing funds resulted from greater business risks.

The slower adjustment speed of a particular industry is attributable to high adjustment costs occuring in the concerning sector. If adjustment costs are relatively higher compared to being off-target costs, then adjustment speed would be slower (Hovakimian et al., 2001). Additionally, sector-related adjustment costs would influence costs borne by firms in rebalancing their leverage; thus, adjustment speed of a particular industry in average would be affected by these costs (Elsas \& Florysiak, 2008). Generally, the firms' manager would consider the trade-off choices be- tween adjustment costs and being off-target costs (Antoniou et al., 2008).

Firm size positively affects the debt ratio within the Agriculture and Property firms mainly due to large firms are more stable, lower agency costs and higher debt capacity to obtain greater tax shield benefits (Sbeiti, 2010). Nevertheless, this variable shows a negative influence among Basic Industry and Infrastructure firms due to large firms being less asymmetrical information and possessing better accessibility in equity market (Rajan \& Zingales, 1995).

Growth opportunity shows a positive relationship with leverages among Agriculture firms due to the firms with greater investment opportunity in this sector having exhausted their internal resources, and their need for more external debt financing (Michaelas, Chittenden, \& Poutziouris, 1999). Profitability affects negatively the debt ratio among Agriculture, Miscellaneous Industry, and Trade and Service firms due to the profitable firms in these sectors having accumulated their profits to be used as source of financing (Antoniou et al., 2008).

Asset tangibility impacts positively on leverage among Trade and Service firms, because these firms rely more on tangible asset to be used as collateral in order to acquire more credit (de Haas \& Peeters, 2006). Liquidity has a negative relationship with leverage within Basic Industry firms, because they utilize their liquid asset as primary source of financing (Ozkan, 2001). The firm's risk negatively affects leverage among Infrastructure and Trade and Service firms due to inability to pay their obligation as their earning becomes more volatile (de Haas \& Peeters, 2006).

\subsection{Impact of industry-specific variable on adjustment speed across sectors}

In this subsection, the discussion emphasizes the impact of industry-specific variables on the speed of adjustment or SOA $(\lambda)$ toward target leverages. Based on Table 5, the adjustment speeds across sectors for each period can be seen in Table 6 .

As previously mentioned, industry-specific variables in this study focus on three covariates, name- 
Table 5. Across sectors analysis using firm-specific determinants

\begin{tabular}{|c|c|c|c|c|c|c|c|c|c|c|c|c|c|c|c|c|}
\hline SECTOR & \multicolumn{2}{|c|}{ 1_Agriculture } & \multicolumn{2}{|c|}{ 2_Mining } & \multicolumn{2}{|c|}{ 3_Basic Ind. } & \multicolumn{2}{|c|}{ 4_Miscellaneous } & \multicolumn{2}{|c|}{ 5_Con Good Ind. } & \multicolumn{2}{|c|}{ 6_Property } & \multicolumn{2}{|c|}{ 7_Infrastructure } & \multicolumn{2}{|c|}{ 8_Trade Service } \\
\hline Dep. variable & \multicolumn{2}{|c|}{$\mathrm{BDR}_{\mathrm{t}+1}$} & \multicolumn{2}{|c|}{$\mathrm{BDR}_{\mathrm{t}+1}$} & \multicolumn{2}{|c|}{ BDR $_{t+1}$} & \multicolumn{2}{|c|}{$\mathrm{BDR}_{\mathrm{t}+1}$} & \multicolumn{2}{|c|}{$\mathrm{BDR}_{\mathrm{t}+1}$} & \multicolumn{2}{|c|}{$\mathrm{BDR}_{\mathrm{t}+1}$} & \multicolumn{2}{|c|}{$\mathrm{BDR}_{\mathrm{t}+1}$} & \multicolumn{2}{|c|}{$\mathrm{BDR}_{\mathrm{t}+1}$} \\
\hline No. of firms/obs. & \multicolumn{2}{|c|}{$21 / 153$} & \multicolumn{2}{|c|}{$42 / 315$} & \multicolumn{2}{|c|}{$59 / 480$} & \multicolumn{2}{|c|}{$36 / 324$} & \multicolumn{2}{|c|}{$35 / 307$} & \multicolumn{2}{|c|}{$52 / 425$} & \multicolumn{2}{|c|}{$50 / 335$} & \multicolumn{2}{|c|}{$112 / 815$} \\
\hline C & -0.468 & 0.218 & 0.215 & $0.055^{*}$ & 0.488 & $0.015^{* *}$ & -0.287 & 0.516 & -0.494 & 0.201 & -0.450 & $0.001^{* * *}$ & 2.731 & $0.000^{* * *}$ & 0.148 & 0.257 \\
\hline SIZE & 0.035 & $0.095^{*}$ & -0.009 & 0.177 & -0.018 & $0.088^{*}$ & 0.024 & 0.305 & 0.030 & 0.139 & 0.029 & $0.000^{* * *}$ & -0.139 & $0.000^{* * *}$ & -0.002 & 0.759 \\
\hline GROW & 0.004 & $0.070^{*}$ & 0.005 & 0.236 & 0.002 & 0.802 & 0.001 & 0.966 & 0.004 & 0.299 & -0.001 & 0.909 & 0.007 & 0.804 & -0.006 & 0.211 \\
\hline PROF & -0.229 & $0.072^{*}$ & -0.010 & 0.861 & -0.008 & 0.921 & -0.313 & $0.078^{*}$ & 0.080 & 0.234 & -0.123 & 0.223 & -0.009 & 0.967 & -0.141 & $0.061^{*}$ \\
\hline TANG & -0.073 & 0.135 & 0.011 & 0.707 & -0.036 & 0.290 & -0.018 & 0.654 & -0.001 & 0.991 & -0.001 & 0.963 & -0.037 & 0.401 & 0.044 & $0.083^{*}$ \\
\hline LIQU & 0.000 & 0.799 & 0.000 & 0.923 & -0.010 & $0.023^{* *}$ & -0.019 & 0.128 & -0.008 & 0.159 & 0.000 & 0.880 & -0.006 & 0.499 & -0.001 & 0.457 \\
\hline RISK & 0.402 & 0.657 & -0.233 & 0.686 & -2.245 & 0.266 & 2.457 & 0.563 & 0.516 & 0.144 & -1.943 & 0.278 & -0.914 & $0.000^{* * *}$ & -1.431 & $0.000^{* * *}$ \\
\hline $\mathrm{BDR}_{2005}$ & 0.777 & $0.000^{* * *}$ & 0.821 & $0.000^{* * *}$ & 0.663 & $0.000^{* * *}$ & 0.687 & $0.000^{* * *}$ & 0.744 & $0.000^{* * *}$ & 0.826 & $0.000^{* * *}$ & 0.369 & $0.078^{*}$ & 0.546 & $0.000^{* * *}$ \\
\hline $\mathrm{BDR}_{2006}$ & 0.403 & $0.001^{* * *}$ & 0.398 & $0.000^{* * *}$ & 0.663 & $0.000^{* * *}$ & 0.728 & $0.000^{* * *}$ & 0.471 & $0.000^{* * *}$ & 0.774 & $0.000^{* * *}$ & 0.521 & $0.010^{* * *}$ & 0.339 & $0.000^{* * *}$ \\
\hline $\mathrm{BDR}_{2007}$ & 0.641 & $0.000^{* * *}$ & 0.715 & $0.000^{* * *}$ & 0.735 & $0.000^{* * *}$ & 0.883 & $0.000^{* * *}$ & 0.626 & $0.000^{* * *}$ & 0.643 & $0.000^{* * *}$ & 0.378 & $0.004^{* * *}$ & 0.525 & $0.000^{* * *}$ \\
\hline $\mathrm{BDR}_{2008}$ & 0.607 & $0.000^{* * *}$ & 0.816 & $0.000^{* * *}$ & 0.557 & $0.000^{* * *}$ & 0.761 & $0.000^{* * *}$ & 0.597 & $0.000^{* * *}$ & 0.630 & $0.000^{* * *}$ & 0.700 & $0.000^{* * *}$ & 0.486 & $0.000^{* * *}$ \\
\hline $\mathrm{BDR}_{2009}$ & 0.588 & $0.000^{* * *}$ & 0.645 & $0.000^{* * *}$ & 0.594 & $0.000^{* * *}$ & 0.735 & $0.000^{* * *}$ & 0.583 & $0.000^{* * *}$ & 0.561 & $0.000^{* * *}$ & 0.748 & $0.000^{* * *}$ & 0.498 & $0.000^{* * *}$ \\
\hline $\mathrm{BDR}_{2010}$ & 0.581 & $0.000^{* * *}$ & 0.716 & $0.000^{* * *}$ & 0.638 & $0.000^{* * *}$ & 0.531 & $0.000^{* * *}$ & 0.330 & $0.000^{* * *}$ & 0.502 & $0.000^{* * *}$ & 0.896 & $0.000^{* * *}$ & 0.388 & $0.000^{* * *}$ \\
\hline $\mathrm{BDR}_{2011}$ & 0.580 & $0.000^{* * *}$ & 0.809 & $0.000^{* * *}$ & 0.618 & $0.000^{* * *}$ & 0.707 & $0.000^{* * *}$ & 0.525 & $0.000^{* * *}$ & 0.501 & $0.000^{* * *}$ & 0.870 & $0.000^{* * *}$ & 0.518 & $0.000^{* * *}$ \\
\hline $\mathrm{BDR}_{2012}$ & 0.629 & $0.000^{* * *}$ & 0.765 & $0.000^{* * *}$ & 0.671 & $0.000^{* * *}$ & 0.747 & $0.000^{* * *}$ & 0.515 & $0.000^{* * *}$ & 0.518 & $0.000^{* * *}$ & 1.119 & $0.000^{* * *}$ & 0.495 & $0.000^{* * *}$ \\
\hline $\mathrm{BDR}_{2013}$ & 0.653 & $0.000^{* * *}$ & 0.833 & $0.000^{* * *}$ & 0.651 & $0.000^{* * *}$ & 0.723 & $0.000^{* * *}$ & 0.558 & $0.000^{* * *}$ & 0.630 & $0.000^{* * *}$ & 0.842 & $0.000^{* * *}$ & 0.558 & $0.000^{* * *}$ \\
\hline $\mathrm{BDR}_{2014}$ & 0.752 & $0.000^{* * *}$ & 0.837 & $0.000^{* * *}$ & 0.527 & $0.000^{* * *}$ & 0.688 & $0.000^{* * *}$ & 0.572 & $0.000^{* * *}$ & 0.606 & $0.000^{* * *}$ & 1.013 & $0.000^{* * *}$ & 0.688 & $0.000^{* * *}$ \\
\hline $\mathrm{BDR}_{2015}$ & 0.592 & $0.000^{* * *}$ & 0.760 & $0.000^{* * *}$ & 0.602 & $0.000^{* * *}$ & 0.701 & $0.000^{* * *}$ & 0.234 & $0.006^{* * *}$ & 0.645 & $0.000^{* * *}$ & 0.683 & $0.000^{* * *}$ & 0.646 & $0.000^{* * *}$ \\
\hline$F$-statistics & \multicolumn{2}{|c|}{20.67} & \multicolumn{2}{|c|}{31.01} & \multicolumn{2}{|c|}{35.02} & & & & .88 & & & & & & \\
\hline Prob. F-stat & & & 0.0 & & 0.0 & $\mathrm{O}^{* * *}$ & & & & $00^{* * *}$ & & $\mathrm{O}^{* * *}$ & & & & \\
\hline$R$-square & & & & & 0. & & & & & 307 & & & & & & \\
\hline DW-stat & & & & & 2. & & & & & 209 & & & & & & \\
\hline Instrument & & & & & & & & & & 2 & & 9 & & & & \\
\hline Average SOA & & & & & 37. & & & & & $57 \%$ & & $36 \%$ & & & & \\
\hline Half-life & & & & & 1 & & & & & 07 & & 46 & & & & \\
\hline
\end{tabular}

Note: This model is based on equation (6). The dependent variable is BDR = Book to Debt Ratio, and the independent variables consist of firm-specific variables (i.e., SIZE = firm size, GROW = growth opportunity, PROF = profitability, TANG = tangibility, LIQU = liquidity, RISK = business risk). The sectors consist of AGRI = Agriculture; MINI = Mining; BASI = Basic Industry and Chemical; MISC = Miscellaneous Industry; CONS = Consumers Good Industry; PROP = Property, Real estate, and Building Construction; 7. INFR = Infrastructure, Utility and Transportation; TRAD = Trade, Service and Investment. Model-fit statistics are reported at the bottom of the table, $p$-values are *** significant at $1 \%$ level, $* *$ significant at $5 \%$ level, * significant at $10 \%$ level. 
ly industry concentration, munificence, and dynamism. The strategy to measure the direct impacts of these variables on the speed of adjustment is by pooling adjustment speed $(\lambda)$ across sectors $j$ over period $t$ and conducting regression as in equation (7). The regression result can be seen in Table 7.

Based on Breusch-Pagan test, Chow test, and Hausman test; fixed-effect method is selected to estimate equation (7). Table 7 exhibits that industry concentration is positively related to adjustment speeds at $1 \%$ significance level. It implies that firms operating within higher industry concentration are relatively faster adjustment speeds. In other words, firms operating within higher industry concentration need less time to adjust toward target leverage from current debt ratio structure, compared to firms

Table 6. Speed of adjustment $(\lambda)$ across sectors

\begin{tabular}{|c|c|c|c|c|c|c|c|c|}
\hline $\operatorname{SOA}(\lambda)$ & 1_AGRI & 2_MINI & 3_BASI & 4_MISC & 5_CONS & 6_PROP & 7_INFR & 8_TRAD \\
\hline $\boldsymbol{\lambda}_{2005}$ & 0.2233 & 0.1789 & 0.3370 & 0.3128 & 0.2565 & 0.1745 & 0.6311 & 0.4539 \\
\hline$\lambda_{2006}$ & 0.5967 & 0.6018 & 0.3373 & 0.2721 & 0.5295 & 0.2257 & 0.4786 & 0.6614 \\
\hline$\lambda_{2007}$ & 0.3587 & 0.2845 & 0.2652 & 0.1171 & 0.3736 & 0.3571 & 0.6220 & 0.4753 \\
\hline$\lambda_{2008}$ & 0.3927 & 0.1843 & 0.4426 & 0.2391 & 0.4026 & 0.3695 & 0.3003 & 0.5139 \\
\hline $\boldsymbol{\lambda}_{2009}$ & 0.4117 & 0.3546 & 0.4060 & 0.2645 & 0.4166 & 0.4387 & 0.2516 & 0.5023 \\
\hline $\boldsymbol{\lambda}_{2010}$ & 0.4195 & 0.2837 & 0.3622 & 0.4694 & 0.6696 & 0.4982 & 0.1043 & 0.6124 \\
\hline$\lambda_{2011}$ & 0.4202 & 0.1905 & 0.3820 & 0.2932 & 0.4746 & 0.4993 & 0.1299 & 0.4819 \\
\hline$\lambda_{2012}$ & 0.3711 & 0.2353 & 0.3293 & 0.2532 & 0.4855 & 0.4822 & $0.1194 *)$ & 0.5052 \\
\hline $\boldsymbol{\lambda}_{2013}$ & 0.3470 & 0.1666 & 0.3492 & 0.2770 & 0.4418 & 0.3703 & 0.1577 & 0.4423 \\
\hline$\lambda_{2014}$ & 0.2479 & 0.1626 & 0.4728 & 0.3122 & 0.4280 & 0.3936 & $\left.0.0131^{*}\right)$ & 0.3124 \\
\hline$\lambda_{2015}$ & 0.4080 & 0.2403 & 0.3981 & 0.2990 & 0.7660 & 0.3554 & 0.3174 & 0.3540 \\
\hline Average SOA & 0.3815 & 0.2621 & 0.3711 & 0.2827 & 0.4767 & 0.3786 & $26.00 \%$ & 0.4832 \\
\hline
\end{tabular}

Note: * Since the coefficient of lag debt ratio more than 1 , the firms made excessive adjustment than necessary and eventually was unable to achieve their optimum level. This table shows adjustment speed across sectors over study period. The sectors consist of: $\mathrm{AGRI}=$ Agriculture; $\mathrm{MINI}=$ Mining; BASI = Basic Industry and Chemical; MISC = Miscellaneous Industry; CONS = Consumers Good Industry; PROP = Property, Real estate, and Building Construction; INFR = Infrastructure, Utility and Transportation; TRAD = Trade, Service and Investment.

Table 7. Impact of industry specific variable on SOA

\begin{tabular}{|c|c|c|c|c|c|c|}
\hline \multirow{3}{*}{ Dep. var.: SOA $(\lambda)$} & \multicolumn{3}{|c|}{ Pooled OLS } & \multicolumn{2}{|c|}{ Fixed effect } & \multirow{2}{*}{$\frac{\text { Random effect }}{\text { SOA }}$} \\
\hline & \multicolumn{3}{|c|}{ SOA $_{i+}$} & \multicolumn{2}{|c|}{ SOA $_{i+}$} & \\
\hline & Coef. & Prob. & Coef. & Prob. & Coef. & Prob. \\
\hline No. of sectors & \multicolumn{3}{|c|}{8} & \multicolumn{2}{|c|}{8} & 8 \\
\hline No. of observations & \multicolumn{3}{|c|}{88} & \multicolumn{2}{|c|}{88} & 88 \\
\hline C & 0.3651 & $0.0000^{* * *}$ & 0.0635 & 0.3602 & 0.2618 & $0.0001^{* * *}$ \\
\hline $\mathrm{HHIC}$ & -0.1965 & 0.1652 & 1.5685 & $0.0006^{* * *}$ & 0.3498 & 0.1955 \\
\hline MUNI & 0.2362 & 0.1353 & 0.5149 & $0.0347^{* *}$ & 0.3266 & $0.0450^{* *}$ \\
\hline DYNA & -0.2698 & 0.7920 & -0.1776 & 0.8832 & 0.0953 & 0.9315 \\
\hline$R$-squared & 0.0531 & - & 0.5641 & - & 0.0733 & - \\
\hline Adjusted $R$-squared & 0.0193 & - & 0.4340 & - & 0.0402 & - \\
\hline S.E. of regression & 0.1413 & - & 0.1073 & - & 0.1150 & - \\
\hline F-statistic & 1.5707 & - & 4.3350 & - & 2.2159 & - \\
\hline \multirow[t]{2}{*}{ Prob. (F-statistic) } & 0.2025 & - & 0.0000 & $* * *$ & $0.0922^{*}$ & - \\
\hline & & & & \multicolumn{2}{|c|}{ Chi-Sq. } & Prob. \\
\hline \multicolumn{4}{|c|}{ LM test for panel data (Breusch-Pagan) } & \multicolumn{2}{|c|}{20.28957} & $0.0000^{* * *}$ \\
\hline \multicolumn{4}{|c|}{ Redundant Fixed Effects Test (Chow test) } & \multicolumn{2}{|c|}{68.2647} & $0.0000^{* * *}$ \\
\hline \multicolumn{4}{|c|}{ Correlated Random Effects (Hausman test) } & \multicolumn{2}{|c|}{22.1503} & $0.0001^{* * * *}$ \\
\hline
\end{tabular}

Note: This model is based on equation (7). The dependent variable is the speed of adjustment $(\lambda)$, and the independent variables are industry-specific variables (i.e. $\mathrm{HHIC}=$ industry concentration, $\mathrm{MUNI}=$ industry munificence, and DYNA = industry dynamism). Model-fit statistics are reported at the bottom of the table, $p$-values are $* * *$ significant at $1 \%$ level, $* *$ significant at $5 \%$ level, * significant at $10 \%$ level. 
operating within lower industry concentration. This is mainly due to firms within high concentration industry enjoying lower competition, getting more profit, and consequently having higher financial reserves and easier to get financial access to adjust their leverage position.

Similarly, industry munificence also positively impacts on adjustment speeds at $5 \%$ significance level. It indicates that firms operating within higher industry munificence are relatively quick to adjust toward their optimal debt ratio. This primarily due to these firms operating within abundant resource environment, which leads to higher profitability and more better access to external financing, which can be utilized to adjust their leverage.

However, industry dynamism fails to show significant influence on adjustment speed toward target debt ratio, although it shows a negative association with adjustment speed. It is probably due to firms operateing in high dynamism industry environment being exposed to higher uncertain change and more volatile business; thus, lenders are reluctant to provide credit to high uncertainty industry and risky firms; and, consequently, it makes slower adjustment.

\section{CONCLUSION}

The firm's target leverages exist, and Indonesian firms partially adjust toward their desired leverage, which is observable from the coefficient value significance of lag dependent variable. By using dynamic adjustment model, the country-level analysis shows adjustment speeds toward desired debt ratio being from around $30.20 \%$ to $36.97 \%$ per year. This indicates that Indonesian firms need from around 1.50 years to 1.93 years to adjust back toward desired debt ratio. As industry-specific variables are included in dynamic model, adjustment speeds indicate very small increase. The important role of these variables for adjustment speed is more observable in the sector-level analysis.

As sample firms are divided into sectors, the dynamic model in sector-level analysis demonstrates various adjustment speed across sectors. The variety of adjustment speeds across industries is attributable to industry characteristics, which are related to sector-based adjustment costs. The fastest adjustment speeds can be seen among Trade and Service firms at $48.32 \%$ per year and followed by Consumer Good Industry firms at $47.62 \%$ per year, whereas the slowest adjustment speed occurs within Infrastructure firms at $26.00 \%$ per year.

Lastly, some of industry-specific variables significantly influence adjustment speeds toward target debt ratio structure. Industry concentration and industry munificence positively affect adjustment speeds. As industry concentration of a particular sector increases (high concentration), adjustment speeds tend to be faster. Similarly, when an industry becomes more abundant of resource (high munificence), adjustment speeds are likely to be quicker. However, industry dynamism shows insignificant negative impact on adjustment speed toward target leverage. In other words, as environment of industry becomes uncertain (high dynamism), adjustment speed tends to decrease, although it is not significant.

\section{RESEARCH CONTRIBUTIONS}

This study provides firm's managers with valuable guidance about the importance of the industry-specific factor in dynamic capital structure framework. Firm's managers might consider firm's position within an appropriate sector, due to each industry having unique characteristics, which affects the firm's optimal debt ratio, as well as adjustment speed toward target leverage. This study also provides empirical literature regarding the variety of optimal financial structure and adjustment speed across industries, particularly within Indonesian context as an emerging and fast-growing market. 


\section{REFERENCES}

1. Almazan, A., \& Molina, C. A. (2005). Intra-industry capital structure dispersion. Journal of Economics and Management Strategy, 14(2), 263-297. https:// doi.org/10.1111/j.15309134.2005.00042.x

2. Ameer, R. (2010). Financial liberalization and firms' capital structure adjustments evidence from Southeast Asia and South America. Journal of Economics and Finance, 37(1), 1-32. https://doi. org/10.1007/s12197-010-9158-3

3. Antoniou, A., Guney, Y., \& Paudyal, K. (2008). The Determinants of Capital Structure: Capital MarketOriented versus Bank-Oriented Institutions. Journal of Financial and Quantitative Analysis, 43(1), 59-92. https://doi.org/10.1017/ S0022109000002751

4. Banerjee, S., Heshmati, A., \& Wihlborg, C. (2000). The Dynamics of Capital Structure (SSE/EFI Working Paper Series in Economics and Finance No. 333).

5. Bilal, A. R., Ramakrishnan, S., Naveed, M., Abu Talib, N. B., Anuar, M. A., \& Khan, M. N. A. A. (2014). Effects of Internal and Environmental Factors on Firm's Financial Behavior: A Comparative Study of Developed, Emerging and Developing Economies. World Applied Sciences Journal, 30(10), 12831293. http://dx.doi.org/10.5829/ idosi.wasj.2014.30.10.14168

6. Bond, S. R. (2002). Dynamic panel data models: a guide to micro data methods and practice. Portuguese Economic Journal, 1(2), 141-162. https://doi.org/10.1007/s10258002-0009-9

7. Buvanendra, S., Sridharan, P., \& Thiyagarajan, S. (2017). Firm characteristics, corporate governance and capital structure adjustments: A comparative study of listed firms in Sri Lanka and India. IIMB Management Review, 29(4), 245-258. https://doi. org/10.1016/j.iimb.2017.10.002

8. Cahyono, S. B., \& Chawla, A. S. (2019a). Firm-Specific
Determinants on Leverages across Sectors in Indonesian Listed Companies. Journal of Emerging Technologies and Innovative Research, 6. Retrieved from https://www.researchgate.net/ publication/332862222_FirmSpecific_Determinants_on_Leverages_across_Sectors_in_Indonesian_Listed_Companies

9. Chakraborty, I. (2010). Capital structure in an emerging stock market: The case of India. Research in International Business and Finance, 24(3), 295-314. https://doi.org/10.1016/j.ribaf.2010.02.001

10. Chen, J., \& Strange, R. (2005). The determinants of capital structure: Evidence from Chinese listed companies. Economic Change and Restructuring, 38(1), 11-35. https://doi.org/10.1007/s10644005-4521-7

11. de Haas, R., \& Peeters, M. (2006). The dynamic adjustment towards target capital structures of firms in transition economies. Economics of Transition, 14(1), 133-169. https://doi.org/10.1111/j.14680351.2006.00237.x

12. DeAngelo, H., \& Masulis, R. W. (1980). Optimal capital structure under corporate and personal taxation. Journal of Financial Economics, 8(1), 3-29. https://doi.org/10.1016/0304405X(80)90019-7

13. Eldomiaty, T. I. (2007). Determinants of corporate capital structure: Evidence from an emerging economy. International Journal of Commerce and Management, 17(1-2), 25-43. https://doi. org/10.1108/10569210710774730

14. Elsas, R., \& Florysiak, D. (2008). Empirical Capital Structure Research: New Ideas, Recent Evidence, and Methodological Issues. Discussion Papers in Business Administration, 6. Munich, Germany: University of Munich. https://doi.org/10.5282/ ubm/epub.4743

15. Elsas, R., \& Florysiak, D. (2011). Heterogeneity in the Speed of Adjustment toward Target Leverage. International Review of Finance, 11(2), 181-211. https://doi.org/10.1111/j.14682443.2011.01130.x

16. EUIBN, E.-I. B. N. (2017). Introduction to the Indonesian Market: Selected Sectors \& Special Economic Zones (J. Ulrich, Ed.) (1st ed.). EU-Indonesia Business Network (EIBN).

17. Fama, E. F., \& French, K. R. (2002). Testing Trade-Off and Pecking Order Predictions About Dividends and Debt. Review of Financial Studies, 15(1), 1-33. https://doi.org/10.1093/rfs/15.1.1

18. Fischer, E. O., Heinkel, R., \& Zechner, J. (1989). Dynamic Capital Structure Choice: Theory and Tests. The Journal of Finance, 44(1), 19-40. https://doi. org/10.1111/j.1540-6261.1989. tb02402.x

19. Flannery, M. J., \& Rangan, K. P. (2006). Partial adjustment toward target capital structures. Journal of Financial Economics, 79(3), 469-506. https://doi.org/10.1016/j. jfineco.2005.03.004

20. Frank, M. Z., \& Goyal, V. K. (2009). Capital structure decisions: Which factors are reliably important? Financial Management, 38(1), 1-37. https://doi.org/10.1111/j.1755053X.2009.01026.x

21. Getzmann, A., Lang, S., \& Spremann, K. (2014). Target Capital Structure and Adjustment Speed in Asia. Asia-Pacific Journal of Financial Studies, 43, 1-30. https://doi.org/10.1111/ajfs.12038

22. Gujarati, D. N., Porter, D. C., \& Gunasekar, S. (2012). Basic Econometrics. Chennai, India: McGraw Hill Education (India), Pvt. Ltd.

23. Guney, Y., Li, L., \& Fairchild, R. (2011). The relationship between product market competition and capital structure in Chinese listed firms. International Review of Financial Analysis, 20(1), 41-51. https://doi.org/10.1016/j. irfa.2010.10.003 
24. Hardiyanto, A. T., Achsani, N. A., Sembel, R., \& Maulana, T. N. A. (2014a). Testing Trade-Off Theory of Capital Structure: Empirical Evidence from Indonesian Listed Companies. Economics and Finance Review, 3(06), 13-20. Retrieved from https://www. semanticscholar.org/paper/Testing-Trade-Off-Theory-of-CapitalStructure\%3A-from-HardiyantoAchsani/8fa26fc027520ffeaeff76b3 fdaf7e6838e16d94

25. Hardiyanto, A. T., Achsani, N. A., Sembel, R., \& Maulana, T. N. A. (2014b). The Difference of Capital Structure among Industry Sectors in The Indonesia Stock Exchange. Business and Management Review, 3(08), 28-35.

26. Haron, R. (2016). Do Indonesian firms practice target capital structure? A dynamic approach. Journal of Asia Business Studies, 10(3), 318-334. https://doi. org/10.1108/JABS-07-2015-0100

27. Haron, R. (2018). Ownership and Debt Financing: Indonesia Evidence. In Financial Management from an Emerging Market Perspective. https://doi. org/10.5772/intechopen.70618

28. Hatfield, G. B., Cheng, L. T. W., \& Davidson, W. N. (1994). The determination of optimal capital structure: the effect of firm and industry debt ratios on market value. Journal of Financial and Strategic Decisions. Retrieved from https://www.researchgate.net/ publication/237289164_THE_DETERMINATION_OF_OPTIMAL_ CAPITAL_STRUCTURE_THE_ EFFECT_OF_FIRM_AND_INDUSTRY_DEBT_RATIOS_ON_ MARKET_VALUE

29. Hovakimian, A., Opler, T., \& Titman, S. (2001). The DebtEquity Choice. The Journal of Financial and Quantitative Analysis, 36(1), 1-24. https://doi. org/10.2307/2676195

30. Hsiao, C. (2003). Analysis of Panel Data (2nd ed.). New York, USA: Cambridge University Press. https://doi.org/10.1017/ CBO9780511754203

31. Jensen, M., \& Meckling, W. (2012). Theory of the firm:
Managerial behavior, agency costs, and ownership structure. The Economic Nature of the Firm: A Reader, 3, 283-303. https://doi.org/10.1017/ CBO9780511817410.023

32. Kayo, E. K., \& Kimura, H. (2011). Hierarchical determinants of capital structure. Journal of Banking and Finance, 35(2), 358371. https://doi.org/10.1016/j. jbankfin.2010.08.015

33. Kundakchyan, R. M., \& Zulfakarova, L. F. (2014). Current issues of optimal capital structure based on forecasting financial performance of the company. Life Science Journal, 11(6), 368371. Retrieved from https:// www.researchgate.net/publication/289649681_Current_issues_ of_optimal_capital_structure_ based_on_forecasting_financial_ performance_of_the_company

34. Leary, M. T., \& Roberts, M. R. (2005). Do firms rebalance their capital structures? Journal of Finance, 60(6), 2575-2619. https://doi.org/10.1111/j.15406261.2005.00811.x

35. Lemmon, M. L., Roberts, M. R., Zender, J. F., Allen, F., Almeida, H., Amihud, Y., Yilmaz, B. (2008). Back to the Beginning: Persistence and the Cross-Section of Corporate Capital Structure. The Journal of Finance, 63(4), 15751608. https://doi.org/10.1111/ j.1540-6261.2008.01369.x

36. Mackay, P., \& Phillips, G. M. (2005). How Does Industry Affect Firm Financial Structure? The Reviews of Financial Studies, 18(4), 1433-1466. https://doi. org/10.1093/rfs/hhi032

37. Maruli Tua Sitorus, P., Priyarsono, D., Manurung, A. H., \& Maulana, T. N. (2014). Analysis of Capital Structure in Corporate Telecommunications Operators in Indonesia. International Journal of Economics and Management Engineering, 4(3), 64-69.

38. Michaelas, N., Chittenden, F., \& Poutziouris, P. (1999). Financial Policy and Capital Structure Choice in U.K. SMEs: Empirical Evidence from Company Panel
Data. Small Business Economics, 12(2), 113-130. https://doi. org/10.1023/A:1008010724051

39. Mitton, T. (2008). Why have debt ratios increased for firms in emerging markets? European Financial Management, 14(1), 127-151. https://doi.org/10.1111/ j.1468-036X.2007.00430.x

40. Myers, S. C. (1984). The Capital Structure Puzzle. The Journal of Finance, 39(3), 575-592. https:// doi.org/10.1111/j.1540-6261.1984. tb03646.x

41. Myers, S. C., \& Majluf, N. S. (1984). Corporate financing and investment decisions when firms have information that investors do not have. Journal of Financial Economics, 13(2), 187-221. https://doi.org/10.1016/0304405X(84)90023-0

42. Nugroho, S. D., Siregar, H., Manurung, A. H., \& Nuryartono, N. (2015). Speed of Adjustment Towards the Leverage Target Plantation Companies In Indonesia. International Journal of Business and Management Review.

43. Ovtchinnikov, A. V. (2010). Capital structure decisions: Evidence from deregulated industries. Journal of Financial Economics, 95(2), 249-274. https://doi.org/10.1016/j.jineco.2009.10.003

44. Ozkan, A. (2001). Determinants of capital structure and adjustment to long run target: Evidence from UK company panel data. Journal of Business Finance and Accounting, 28(1-2), 175-198. https://doi. org/10.1111/1468-5957.00370

45. Rajan, R. G., \& Zingales, L. (1995). What Do We Know about Capital Structure? The Journal of Finance, 50(5), 14211460. https://doi.org/https://doi. org/10.1111/j.1540-6261.1995. tb05184.x

46. Reinhard, L., \& Li, S. (2010). A note on capital structure target adjustment - Indonesian evidence. International Journal of Managerial Finance, 6(3), 245-259. https://doi. org/10.1108/17439131011056242 
47. Saadah, S., \& Prijadi, R. (2012). Capital Structure's Dynamic Response to Exogenous Variables: A Case of Listed Manufacturing Firms in Indonesia. International Journal of Financial Research, 3(2), 86-95. https://doi.org/10.5430/ijfr.v3n2p86

48. Santi, F. (2003). Determinants of Indonesian Firms' Capital Structure: Panel Data Analysis. Jurnal Ekonomi Dan Bisnis Indonesia, 18(3), 243-260. Retrieved from https://www.researchgate.net/ publication/200072982_Determinants_of_Indonesian_Firms'_Capital_Structure_Panel_Data_Analysis

49. Sbeiti, W. (2010). The Determinants of Capital Structure: Evidence from the GCC Countries. International Research Journal of Finance and Economics, 47, 54-79.

50. Song, H. (2005). Capital Structure Determinants An Empirical Study of Swedish Companies (No. 25) (Working Paper Series in Economics and Institutions of Innovation).

51. Tambunan, T. T. H. (2010). The Indonesian Experience with Two Big Economic Crises. Modern Economy, 1(3), 156-167. https:// doi.org/10.4236/me.2010.13018

52. Thies, C. F., \& Klock, M. S. (1992). Determinants of capital structure. Review of Financial Economics, 1(2), 40-52.
53. Titman, S., \& Wessels, R. (1988). The Determinants of Capital Structure Choice. The Journal of Finance, 43(1), 1-19. https://doi. org/10.1111/j.1540-6261.1988. tb02585.x

54. Wakhidi, M. A. B., \& Sukarno, S. (2014). Capital Structure and Leverage Adjustment in Indonesian State Owned Enterprise. Singapore: 7th Asia-Pacific Business Research Conference.

55. Welch, I. (2004). Capital Structure and Stock Returns. Journal of Political Economy, 112(1), 106-131. https://doi.org/10.1086/379933 